DOI:

\title{
Romatoid Artrit Tedavisinde Uygulanan Güncel Yaklaşımlar
}

\author{
Hevişan AKDAĞ${ }^{1}$, Sahra KIRMUSAOĞLU ${ }^{1 *}$ \\ ${ }^{1}$ Haliç Üniversitesi, Fen Edebiyat Fakültesi, Moleküler Biyoloji ve Genetik \\ Bölümü, İstanbul, Türkiye \\ ORCID ID: orcid.org/ 0000-0003-2290-6156 \\ ORCID ID: orcid.org/0000-0003-3038-1417
}

Geliş Tarihi: 13.02 .2019

*Sorumlu Yazar e mail: sahrakirmusaoglu@halic.edu.tr Kabul Tarihi: 26.09.2019

Atıf/Citation: Akdağ, H. ve Kırmusaoğlu, S. "Romatoid Artrit Tedavisinde Uygulanan Güncel Yaklaşımlar”, Haliç Üniversitesi Fen Bilimleri Dergisi 2019, 2/2: 197-206.

Derleme Makalesi/ Review Article

\section{Özet}

Romatoid artrit (RA), genel popülasyonun yaklaşık \%1'ini etkilediği düşünülen, bağ dokusu hasarını hedef alan kronik bir otoimmün ve insanın bağışıklık sisteminin vücuttaki kendi sağlıklı hücreleriyle savaşması sonucunda ortaya çıkan bir hastalıktır. Romatoid artritli hastalarda, bağ dokusu hasarının ilerlemesi, sakatlığa, hastaların yaşam kalitesinin azalmasına ve mortaliteye sebep olmaktadır. RA'yı tamamen tedavi eden bir tedavi seçeneği henüz yoktur. RA'nın erken tanısı ve tedavisi ile hastaların \%90'ının eklem hasarının ilerlemesi ya da hasar oluşumu yavaşlatılabilir. Geleneksel tedavilerin yetersizliğinden dolayı, romatoid artrit tedavisinin etkili ve spesifik bir biçimde gerçekleşmesi için güncel tedavilere ihtiyaç duyulmaktadır. Bu derlemede, romatoid artrit tedavisinde uygulanan geleneksel tedaviler ve modern terapötik yaklaşımlar ele alınacaktır.

Anahtar Kelimeler: Romatoid artrit, Modern terapötik yaklaşımlar, Geleneksel tedaviler, Otoimmün hastalık

\section{The Recent Approaches Applied in the Treatment of Rheumatoid Arthritis}

\begin{abstract}
Rheumatoid arthritis (RA) is a chronic autoimmune that is thought to affect about $1 \%$ of the general population, and is a disease caused by the human immune system fighting its own healthy cells in the body. RA is a disease that emerges as a result of
\end{abstract}


fighting of human immune system with its own healthy cells. In patients who have rheumatoid arthritis, progression of connective tissue damage leads to disability, decreased quality of life of patients, and mortality. There is not a treatment option yet that treat RA completely. With early diagnosis and the treatment of RA, joint damage progression or formation of damage of $90 \%$ of patients can be decelerated. Due to the insufficiency of traditional treatments, up-to-date treatment options are needed for effective and specific treatment of rheumatoid arthritis. In this review, traditional treatments and modern therapeutic approaches applied in the treatment of RA will be discussed.

Keywords: Rheumatoid arthritis, Modern therapeutic approaches, Traditional treatments, Autoimmune disease

\section{Giriş}

Otoimmün bozukluklar sakatlık ve birçok hastalığın sebebidir. $\mathrm{Bu}$ hastalıkların insan popülasyonundaki bireylerin yaklaşı $\% 8.5$ 'ini etkilediği tahmin edilmektedir [1]. Romatoid artrit (RA), bağışıklık sisteminin kendi sağlıklı hücreleriyle savaştığ bir bağışıklık tepkisinin savaşması sonucu oluşur. RA'in oluşum sebepleri tam olarak anlaşılmamıştır. Yapılan klinik çalışmalar, mikrobiyal enfeksiyonların da artrit ile bağlantılı olduğunu göstermiştir. Yapılan klinik ve hayvan modelli çalışmalarda Staphylococcus aureus, Streptococcus pyogenes, Epstein-Barr virus ve mikoplazma enfeksiyonlarının, RA patogenezine sebep olduğu bulunmuştur $[1,2]$. RA eklem bağ doku bozulmasını içeren kronik bir hastalıktır [3]. Romatoid artritin semptomları arasında yorgunluk, ateş, eklem ağrısı, eklem hassasiyeti ve kilo kaybı bulunmaktadır [2, 3]. RA için risk faktörleri; yaş, cinsiyet, kalıtım, sigara kullanımı ve obezitedir. Cinsiyet farkının temeli net olmamakla beraber kadın-erkek oranının 2-4:1 olduğu bilinmektedir [3].

Romatoid artritin herhangi bir tedavisi yoktur, ancak erken tanı ve uygun tedavi ile bu hastalığa sahip kişilerin hayatını kaliteli bir şekilde sürdürmesine ve çalışmaya devam edebilmesine olanak 
sağlar. $\mathrm{Bu}$ yüzden RA'in tanı ve tedavisindeki mevcut uygulamalar, erken teşhis ve tedavi yönündedir. Erken teşhis sonrasındaki tedavi seçenekleri arasında, steroid olmayan antienflamatuvar ilaçlar (NSAID), steroid hormonlarını içeren glukokortikoidler, hastalık modifiye edici anti-romatizmal ilaçlar, monoklonal antikorlar, biyolojik ajanlar, nanoteknoloji, oral tolerans, gen terapisi, kemik iliği transplantasyonu, lipozomlar, süperparamanyetik demir oksit nano partiküller bulunur $[3,4]$.

\section{Materyal ve Metot (Tedavi Yaklaşımları)}

RA'in tedavisinde geleneksel ve yeni yaklaşımlar mevcuttur.

\subsection{Geleneksel yaklaşımlar}

RA'in tedavisinde geleneksel yaklaşımlar arasında nonstreoid antienflamatuvar ilaçlar, glukokortikoidler, anti romatizmal ilaçlar, monoklonal antikorlar, küçük moleküller bulunur.

\subsubsection{Nonstreoid antienflamatuvar ilaçlar}

NSAID, artrit tedavisinde oldukça yaygın kullanılan ilaçlardan biridir. NSAİD'ler analjezik ve antiinflamatuvar etkilere sahiptir. NSAİD'lerin mekanizması enzim siklooksijenaz (COX) ve inflamasyonu korumaktır. Siklooksijenaz, siklooksijenaz-1 (COX-1) ve siklooksijenaz-2 (COX-2) olmak üzere iki izoenzimatik form yapısına sahiptir [4]. Siklooksijenazın bir formu olan COX-2' nin inhibisyonu, NSAİD' lerin antienflamatuar etki göstermesine neden olurken; COX-1 formunun inhibisyonu ise, mide ve böbrek fonksiyonlarında problemlere neden olur $[4,5]$. NSAİD'lerin, RA tedavisinde yan etkisi gözlemlenmemiştir [6]. 


\subsubsection{Glukokortikoidler}

Glukokortikoidler (GC) bir steroid hormondur. RA tedavisinde yaygin olarak kullanılır. GC'ler kortizol reseptörlerine bağlanarak etkilerini gösterirler. Yüksek etkili bir anti-enflamatuâr ve immünsüpresiftir [7]. Yapılan çalışmalar, uzun süre ve düşük dozda kullanılan glukokortikoidlerin anti-enflamatuar ve immünsüpresif etkilerinin yanı sıra, kemik ve kıkırdak hasarının ilerlemesini büyük ölçüde azaltabileceğini ortaya koymuştur [8,9]. GC'lerin kısa süreli yan etkileri; kilo alımı, hipertansiyon, diyabet, katarakt ve osteoporozdur [9].

\subsubsection{Anti romatizmal ilaçlar}

Anti romatizmal ilaçlar (DMARD'lar) eklem şişliğini, hassasiyetini ve ağrısını azaltır. DMARD'lar iltihabı engelleyerek eklemlerin korunmasına yardımcı olur. DMARD'lar, metotreksatı, sulfasalazini, hidroksiklorokini, siklosporini, altın tuzlarını, penisilamini ve azatioprini içerir. RA tedavisinde DMARD metotreksat en sık kullanılanıdir [7, 8]. RA tedavisinde kullanılan DMARD'lara ek olarak, biyolojik ajanlar olan monoklonal antikorlar ve küçük moleküller de kullanılmaktadır $[9,10]$.

\subsubsection{Monoklonal antikorlar}

Son y1llarda yapılan monoklonal antikor tedavisinin RA'da etkili olduğu görülmüştür. Bu moleküllerin temel etki mekanizması, insan kimerik antikorlara bağlanabilmesidir. $\mathrm{Bu}$ antikorlar temel olarak iki zincirden oluşur. Bu moleküller ve etkileri, iki zincirin, kimerik antikorlara ve birkaç murin bağlanma bölgesine spesifiktir. Bu antikorlar sitokin veya sitokin reseptörüne bağlanarak etki gösterir [8, 9]. Bu tür ajanlar, ilk olarak 1980 yıllarında geliştirilmiştir. RA'da ilk olarak kullanılan monoklonal antikor ajanı, anti-CD4 olmakla birlikte son yıllarda, hedef moleküllere yönelik monoklonal antikorlar tümör 
nekrotizan faktör a (TNF-a), CD20-pozitif B hücreleri, interlökin-1 (IL-1) ve interlökin 6'dır (IL-6) [10, 11].

\subsubsection{Küçük moleküller}

Yeni antiinflamatuar tedaviler, yaklaşık 1 kDa'lık moleküler ağırlıklı küçük moleküller ile uygulanır. Son zamanlarda yapılan bir çalışmada, in vivo ortamda bir artrit sıçan modellinde upadacitinib adlı bir molekülün etkinliği, retikülosit yayılımı üzerindeki etki ve dolaşımdaki doğal katil hücreleri (NK) üzerindeki etki ile tanımlanmıştır. Upadacitinib, genellikle JAK-2, JAK-3 ve nonreseptör tirosin-protein kinaz üzerinde JAK-1'i inhibe ederek, sitokin reseptör sinyallerinin azalmasını sağlayan bir araştırma ilacıdır. In vitro ve in vivo çalışmalar, upadacitinib' in JAK-1'in seçici inhibitörü olduğunu göstermektedir $[12,13]$.

\subsection{Yeni tedavi yöntemleri}

Oral tolerans, lipozomlar, nanoteknoloji, gen terapi ve süper manyetik demir oksit nanopartiküller günümüzde, RA'in tanı ve tedavisindeki yeni yaklaşımların arasında yer almaktadır (Tablo 1.)

Tablo 1. Romatoid artrit için güncel tedaviler

Güncel Tedaviler

1. Oral tolerans

2. Lipozomlar

3. Nanoteknoloji

4. Gen Terapi

5. Süperparamanyetik Demir Oksit Nanopartikülleri 


\subsubsection{Oral tolerans}

RA'da olduğu gibi birçok kronik otoimmün hastalıkların tedavisi için oral toleransın uyarılması umut verici bir tedavi yaklaşımıdır. Oral tolerans; immün sistemin cevabını değiştirebilecek antijenlerin oral uygulamasını kapsar. Oral tolerans, ilk defa 1911 yılında hayvan modellerinde tanımlanmıştır. Ag'ın oral uygulamasının ardından, hangi tolerans formunun ilerleyeceğini belirleyen önemli faktör Ag'nin dozudur [12]. Bu nedenle, düşük dozlu Ag'nin, daha sonra immün sisteme göç eden, sindirim sistemiyle ilişkili lenfoid dokudaki düzenleyici $\mathrm{T}$ hücreleri baskıladığı düşünülür. T hücreleri, bir Th2 / Th3 sitokin olan IL4, IL10 ve tümör büyüme faktörü- $\beta$ (TGF- $\beta$ ) gibi düzenleyici sitokinler üretir. Ag'nin oral yolla uygulanmasından sonra hangi toleransı göstereceğini belirleyen faktör Ag'nin dozudur [12, 13].

\subsubsection{Lipozomlar}

Lipozom kulanımı, 1964'te keşfedilmesinden bu yana yaygın hale gelmiştir. Lipozomlar, ilaç salınım sisteminde yeni bir yöntem olarak kullanılmaktadır. Lipozomlar, fosfolipitlerden meydana gelen ve sulu faza sahip olan çok küçük veziküllerdir. Lipozomlar, geliştirilmiş farmakokinetik ve farmakodinamik, toksisitenin azalması, patojenlere karşı artırılan terapötik verim ve ilaç hedefi seçiciliği gibi avantajları içerir [13]. RA tedavisinde kullanılan, önemli bazı ilaçların seçiciliği ve yüksek terapötik etkinliği için, ilaçların yüksek dozda ve sıklıkla alınımı gerekir. Bununla birlikte, yüksek dozlar ayrıca yan etki riskini de arttırabilmektedir. Lipozomların hedeflendirilmiş ilaç taşıyıcı olarak kullanılması, antiromatizmal ilaçların etkinliğini artırabilir. Lipozomların avantajlarının yanı sıra, yüklü lipitler gibi bazı lipitlerin, yüksek dozlarda toksik hale gelebilmesi, kısa raf ömrüne sahip olması ve stabilitede sorunlar yaşanabilmesi gibi dezavantajları da olabilir [13, 14]. 


\subsubsection{Nanoteknoloji}

Nanoteknoloji ve nanopartiküller, moleküler biyolojide geniş alana sahiptir. Nanoteknoloji, hücreler ve biyomoleküller ile cihazların oluşturulmasını mümkün kılan, görüntüleme, algılama, ilaç salınımı ve temel biyolojik işlemlerin karakterizasyonu için kullanılan bir tedavi yöntemidir. Nanoteknoloji kullanılarak daha hızlı ve daha ucuz tedaviler geliştirilir [15]. Nanopartiküller, ilaçların bozulmadan kapsüllenmesi, hedeflenen ilaç salınımının spesifitesi, kontrollü ilaç salınımının olması için olanak sağlar. Normalde ilaçlar, vücutta hastalığın etki ettiği bölgeye hedeflenmeden önce tüm vücutta etkinlik gösterebilirler. Bu yüzden nanoteknoloji kullanılarak, ilacın, etki edeceği bölgeye hedeflendirilerek, daha etkili olması ve olası yan etkilerinin en aza indirilmesi sağlanır. Nanopartiküllerin avantajları; düşük doz, düşük toksisite, hızlı tedavi ve spesifik hedefe özgü ilaç salınımıdır [15, 16].

\subsubsection{Gen terapi}

Gen terapisi, hastalığı tedavi etmek veya önlemek amacıyla, genlerin tedavisi tekniğidir. Gen terapisi, hatalı bir genin yerine geçmek ya da hastalığı iyileştirmek ve vücudun hastalık ile savaşmasını geliştirmek için yeni hatasız bir gen ekleme sürecini kapsar. Gen terapisi RA, diyabet, hemofili ve AIDS gibi çok çeşitli hastalıkların tedavisinde kullanılır. RA tedavisinde gen terapisi yaklaşımı kulanılmaktadır. Gen terapisi, bir gen ürününün ya da birden fazla ürünün, hedefe özgü bağlanmasını kapsar. RA'da gen terapisi, artrit hastalarının eklemlerine terapötik proteinler iletimi için yeni bir yaklaşım sunmaktadır. İnterlökin-1 (IL-1) gibi enflamatuar sitokinlerin sinoviyal hücrelerin ve kondrositleri sentezlenerek, hastalığın ilerlemesini yavaşlatmaktadır. Enflamatuvar süreçleri bloke etmek veya hasarlı k1kırdak onarımını stimüle etme potansiyeline sahip birçok protein tanımlanmıştır. Proteinlerin çoğu in vivo olarak yarılanma ömrüne sahip olduğundan, etkili olarak uygulama yöntemlerini sınırlandırmaktadır. 
Gen terapisi uygulamalarıyla ekzojen genler, artritik eklemlerin hücre ve dokularına iletilir böylece hastalığın ilerlemesi durdurulabilir. Ex vivo ve in vivo terapötik genlerin iletimi için viral ve viral olmayan vektörler kullanılmıştır. Ex vivo gen iletimi kullanılarak, RA hastalarının eklemlerinde başarılı ve güvenli bir gen aktarımı yapıldığı gösterilmiştir [18].

\subsubsection{Süpermanyetik demir oksit nanopartikülleri}

Son zamanlarda nanopartiküller, laboratuvar teşhisi ve terapötik tedavi yaklaşımlarını kolaylaştırdıkları için biyomedikal uygulamalarda kullanılmaktadır. Süper paramanyetik demir oksit nanopartiküller, sağlamlıklarını arttırmak için hidrofilik bir dekstran ya da biyo-uyumlu bir bileşik ile çekirdek olarak demir oksitten oluşmuştur [19]. Süpermanyetik Demir Oksit Nanopartikülleri (SPION) ve kortikosteroid deksametazon asetat, Poli Laktik-ko-Glikolik Asit (PLGA) mikropartikülleri içinde birlikte kapsüllenir. RA'nın tedavisinde eklemde mikropartiküllerin kalma süresini artırır [19, 22].

\section{Sonuçlar}

RA heterojen bir hastalıktır ve tedaviye cevabı kesin olarak öngürülememektedir. Bu hastalıkta erken tanı ve tedavinin hastalardaki yapısal hasarların azalması ve hastalık sürecinde bireylerin hayat kalitesinin artmasına katkıda bulunacağı kanıtlanmıştır. RA'nın şiddetini azaltmak için NSAID'ler, kortikosteroidler, DMARD'ler gibi geleneksel tedaviler kullanılır. Fakat bu geleneksel tedavilerin uzun süreli uygulanması, kullanılan ajanların hastalarda yan etkiye sebep olmasından dolayı tedavilerde yetersiz kalmıştır. Geleneksel tedavilerin artritte kullanılmasıyla, eklem hasarının ve kararsızlığının önlenmesi amaçlanır. Geleneksel tedavilere cevap vermeyen hastalar için yeni tedavi yöntemlerine ihtiyaç duyulmuştur. Bu derlemede yeni tedavi yöntemleri özetlenmiştir 


\section{Kaynaklar}

[1] Hashemi, M., Atabaki, M.,Daneshvar , H., et al. Association of PTPN22 rs2476601 and EGFR rs17337023 Gene polymorphisms and rheumatoid arthritis in Zahedan, Southeast Iran. Int J Immunogenet. 40 (4), (2013), 299-305. DOI: https://doi.org/10.1111/iji.12038

[2] J, Becker., KL,Winthrop., Update on rheumatic manifestations of infectious diseases. Curr Opin Rheumatol. 22 (1), (2010), 72-7. DOI: 10.1097/BOR. 0b013e328333b9f5.

[3] http://www.who.int/chp/topics/rheumatic/en/ (Erişim tarihi:15 aralık 2018).

[4] B., S., Ma, T., Genovese, M., \& Lane Smith, R. et al. Cox-2 Selective Inhibitors and Bone. International Journal of Immunopathology and Pharmacology, (2003), 201-205. DOI: https://doi.org/10.1177/039463200301600303

[5] Furst, DE., Meloxicam: selective COX-2 inhibition in clinical practice. Semin Arthritis Rheum. 26 (1), (1997), 21-27. DOI: https://doi.org/10.1016/S00490172(97)80049-2

[6] 2002 Update American College of Rheumatology Subcommitee on Rheumatoid Arthtitis Guidelines. Guidelines for the management of rheumatoid arthritis: Arthritis Rheum. 46 (2), (2002), 328-346. DOI: 10.1002/art.10148

[7] Quan, L.,Macromolecular Nanomedicine of Glucocorticoids for the Treatment of Rheumatoid Arthritis. J Nanomed Nanotechol. 4 (1), (2013) ,126. DOI: $10.4172 / 2157-7439.1000 \mathrm{e} 126$

[8] Kirwan, J., Boers, M., Low dose prednisolone for treatment of RA Annals of the Rheumatic Diseases. 63 (11), (2004), 1533-1534. DOI: http://ard.bmj.com/ content/63/11/1533.

[9] Wendling, D., Wijdenes, J., Racadot, E., Therapeutic use of monoclonal anti-CD4 antibody in rheumatoid arthritis. J. Rheumatol. 18 (3), (1991), 325-327. DOI: https://doi.org/10.1046/j.1365-2036.1996.59201000.x

[10] Van de, Putte., Atkins, C., Malaise, M., et al. Efficacy and safety of adalimumab as monotherapy in patients with rheumatoid arthritis for whom previous diseasemodifying antirheumatic drug treatment has failed. Ann. Rheum. Dis. 63, (2004), 508-516. DOI: 10.1136/ard.2003.013052

[11] Jacobs, JWG., Everdingen, AAV., Verstappen, SMM., et al. Followup radiographic data on patients with rheumatoid arthritis who participated in a two-year trial of prednisone therapy or placebo. Arthritis Rheum. 54 (5), (2006), 14221428. DOI: https://doi.org/10.1002/art.21809

[12] Smolen, JS., Aletaha, D., Koeller, M., New therapies for treatment of rheumatoid arthritis. Lancet. 370 (9602), (2007), 1861-1874. DOI: 10.1016/S01406736(07)60784-3 
[13] Parmentier, J., Voss, J., Graff, C., et al. In vitro and in vivo characterization of the JAK1 selectivity of upadacitinib (ABT-494). BMC Rheumatology. 2 (23), (2018), 1. DOI: https://doi.org/10.1186/s41927-018-0031-x

[14] Toussirot, EA., Oral tolerance in the treatment of rheumatoid arthritis. Curr Drug Targets Inflamm Allergy. 1 (1), (2002), 45-52. DOI: https://doi. org/10.2174/1568010023344850

[15] Gregoriadis, G., Drug entrapment in liposomes. FEBS Lett. 36 (3), (1973), 292-296. DOI: https://doi.org/10.1016/0014-5793(73)80394-1

[16] Arora, R., Kuhad, A., Kaur, I.P., et al. Curcumin loaded solid lipid nanoparticles ameliorate adjuvant-induced arthritis in rats. European Journal of Pharmacology. 19 (7), (2014), 940-952. DOI: https://doi.org/10.1002/ejp.620

[17] Allen,TM., Hansen, C., Martin, F., et al. Liposomes containing synthetic lipid derivatives of poly(ethylene glycol) show prolonged circulation half-lives in vivo. Biochim Biophys Acta. 1066 (1), (1991), 29-36. DOI: http://dx.doi. org/10.1016/0005-2736(91)90246-5

[18] Samad, A., Sultana, Y., Aqil, M., Liposomal Drug Delivery Systems: an update review, Current drug delivery. 4 (4), (2007), 297-305. DOI: $0.2174 / 156720107782151269$

[19] Wehling, P., Reinecke, J., Baltzer, A. W., et al. Clinical responses to gene therapy in joints of two subjects with rheumatoid arthritis. Human gene therapy, 20(2), (2009), 97-101. DOI: 10.1089/hum.2008.075

[20] Evans, C. H., Ghivizzani, S. C., \& Robbins, P. D., Arthritis gene therapy's first death. Arthritis research \& therapy.10 (3), (2008), 110. DOI: 10.1186/ar2411

[21] Scheller, E. L., \& Krebsbach, P. H. Gene therapy: design and prospects for craniofacial regeneration. Journal of dental research.88 (7), (2009), 585-96. DOI: $10.1177 / 0022034509337480$

[22] Mahmoudi, M., Sant, S., Wang, B., et al. Superparamagnetic iron oxide nanoparticles (SPIONs): Development, surface modification and applications in chemotherapy.Adv Drug Deliv Rev. 63 (1-2),(2011), 24-46. DOI: 10.1016/j. addr.2010.05 